\title{
Correction to: Efficacy of mesenchymal stem cell therapy in systolic heart failure: a systematic review and meta-analysis
}

Mengkang Fan ${ }^{1 \dagger}$, Yin Huang ${ }^{2+}$, Zhangwei Chen ${ }^{1}$, Yan Xia ${ }^{1}$, Ao Chen ${ }^{1}$, Danbo Lu', Yuan Wu ${ }^{1}$, Ning Zhang ${ }^{1}$ and Juying Qian ${ }^{1 *}$

\section{Correction to: Stem Cell Res Ther (2019) 10:150 \\ https://doi.org/10.1186/s13287-019-1258-1}

The original article [1] displayed a co-author, Junbo Ge who has since stated that he should not have been a co-author in the article; the article has now been amended to remove Junbo Ge accordingly. All authors agreed to this amendment.

\footnotetext{
Author details

'Department of Cardiology, Shanghai Institute of Cardiovascular Diseases, Zhongshan Hospital, Fudan University, 180 Fenglin Road, Shanghai 200032, China. ${ }^{2}$ Department of Geriatric Medicine, Affiliated Hospital of Nantong University, Nantong, Jiangsu, China.
}

Received: 5 July 2019 Revised: 5 July 2019

Accepted: 5 July 2019 Published online: 15 July 2019

\section{Reference}

1. Fan M, Huang Y, Chen Z, Xia Y, Chen A, Lu D, et al. Efficacy of mesenchymal stem cell therapy in systolic heart failure: a systematic review and metaanalysis. BMC Med. 2019;10:150. https://doi.org/10.1186/s13287-019-1258-1.

* Correspondence: qian.juying@zs-hospital.sh.cn

${ }^{\dagger}$ Mengkang Fan and Yin Huang contributed equally to this work.

${ }^{1}$ Department of Cardiology, Shanghai Institute of Cardiovascular Diseases,

Zhongshan Hospital, Fudan University, 180 Fenglin Road, Shanghai 200032,

China

Full list of author information is available at the end of the article

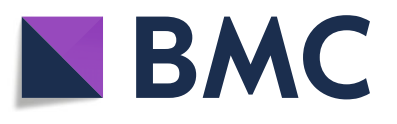

(c) The Author(s). 2019 Open Access This article is distributed under the terms of the Creative Commons Attribution 4.0 International License (http://creativecommons.org/licenses/by/4.0/), which permits unrestricted use, distribution, and reproduction in any medium, provided you give appropriate credit to the original author(s) and the source, provide a link to the Creative Commons license, and indicate if changes were made. The Creative Commons Public Domain Dedication waiver (http://creativecommons.org/publicdomain/zero/1.0/) applies to the data made available in this article, unless otherwise stated. 